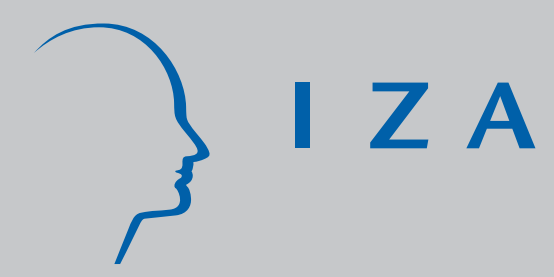

IZA DP No. 958

Creating Low Skilled J obs by Subsidizing Market-Contracted Household Work

\author{
Tilman Brück \\ J ohn P. Haisken-DeNew \\ Klaus F. Zimmermann
}

December 2003 


\title{
Creating Low Skilled Jobs by Subsidizing Market-Contracted Household Work
}

\author{
Tilman Brück \\ DIW Berlin \\ John P. Haisken-DeNew \\ RWI Essen and IZA Bonn \\ Klaus F. Zimmermann \\ IZA Bonn, University of Bonn and DIW Berlin \\ Discussion Paper No. 958 \\ December 2003 \\ IZA \\ P.O. Box 7240 \\ D-53072 Bonn \\ Germany \\ Tel.: +49-228-3894-0 \\ Fax: +49-228-3894-210 \\ Email: iza@iza.org
}

This Discussion Paper is issued within the framework of IZA's research area The Future of Labor. Any opinions expressed here are those of the author(s) and not those of the institute. Research disseminated by IZA may include views on policy, but the institute itself takes no institutional policy positions.

The Institute for the Study of Labor (IZA) in Bonn is a local and virtual international research center and a place of communication between science, politics and business. IZA is an independent, nonprofit limited liability company (Gesellschaft mit beschränkter Haftung) supported by Deutsche Post World Net. The center is associated with the University of Bonn and offers a stimulating research environment through its research networks, research support, and visitors and doctoral programs. IZA engages in (i) original and internationally competitive research in all fields of labor economics, (ii) development of policy concepts, and (iii) dissemination of research results and concepts to the interested public. The current research program deals with (1) mobility and flexibility of labor, (2) internationalization of labor markets, (3) welfare state and labor market, (4) labor markets in transition countries, (5) the future of labor, (6) evaluation of labor market policies and projects and (7) general labor economics.

IZA Discussion Papers often represent preliminary work and are circulated to encourage discussion. Citation of such a paper should account for its provisional character. A revised version may be available on the IZA website (www.iza.org) or directly from the author. 
IZA Discussion Paper No. 958

December 2003

\section{ABSTRACT \\ Creating Low Skilled Jobs by Subsidizing Market-Contracted Household Work*}

We analyze the determinants of household work contracted in the German shadow economy. The German socio-economic household panel, which enumerates casual domestic employment, is used to estimate the demand for such household work. The regressors include regional wage rates, household income and several control variables for household composition. We find that the demand for household work in the shadow economy is very income elastic. This suggests that targeted wage subsidies, linked to household work agencies, would be very effective in raising the legal demand for domestic help. A wage subsidy of $50 \%$ of wage costs could thus establish up to 500,000 new jobs for previously unemployed or non-working low skilled workers. The net fiscal costs of such a scheme are about 6.200 Euro per full-time job. In addition, society benefits from more law enforcement and from a raised female labor supply, especially by highly qualified mothers.

JEL Classification: D13, H24, J23, K42

Keywords: labor demand, wage subsidy, household services, low skilled unemployment, shadow economy, GSOEP

Corresponding author:

Klaus F. Zimmermann

IZA

P.O.Box 7240

53072 Bonn

Germany

Phone: +492283894200

Fax: +492283894210

Email: zimmermann@iza.org

\footnotetext{
* The authors would like to thank Holger Bonin, Hilmar Schneider and Jürgen Schupp for helpful comments. The data used in this study is available upon request from the German Socio-Economic Panel at the DIW Berlin (www.diw.de/gsoep).
} 
An interesting characteristic of the German labor market is the co-existence of an extremely high unemployment rate for low -skilled workers and the non-participation in the labor market of well educated mothers. In fact, $23 \%$ of the low skilled were unemployed in West Germany in 1998 and 54\% in East Germany (Reinberg 1999: 435). This contrasts with labor market participation rates in Germany in the year 2000 for university-trained, married women aged 18 to 65 with children aged 0 to 1 year, 0 to 4 years and 0 to 7 years of only $26.5 \%, 47.0 \%$ and $56.8 \%$, respectively (GSOEP data).

There are a number of possible explanations for this paradox, among them the prohibitive non-wage labor costs for low -skilled jobs, large transaction costs in the market for domestic labor preventing market clearing, steep marginal tax rates for part-time spouses, and a poor child-care infrastructure. This article addresses the role of the first two factors by analyzing the demand for marketcontracted household work (MCHW). In most instances, this labor is hired in the shadow economy, due to the high non-wage costs and to the small chance of detection of such illegal employment in private homes.

We identify the determinants of such illegal domestic employment using data from the German socio-economic household panel (GSOEP). This dataset includes a question about households hiring domestic help, skirting the issue of its legality. This data is matched with information on the regional wage rates of domestic workers. Based on a household timeallocation framework, we estimate the demand for market-contracted housework previously employed in the shadow economy. We assume that labor supply can be organized through work agencies. In a further step, we then simulate the effects of different levels of wage subsidies through the work agencies on the labor supply of low skilled workers and calculate the fiscal costs of these policies. 
While other studies have focused on estimating the size of the shadow economy or the value of the non-marketed household sector, we model the reaction of the shadow economy to a wage subsidy. In effect, we analyze the costs and benefits to legalize the shadow market for housework by introducing the service agencies.

Our paper also builds on the literature of wage subsidies for the low skilled. Given the peculiarities of the market for housework (which include a large degree of illegal work), wage subsidies in this sector can be much more effective than wage subsidies in the economy at large. The domestic work sector is hence one of the sectors most suited for implementing a labor demand subsidy for the low skilled. In view of the large rates of unemployment of the low skilled in Germany, such a subsidy may pay large social dividends. Our proposal of a wage subsidy of up to $50 \%$ of wage costs would compensate non-wage labor costs thus reducing the incentives for illegal employment and potentially inducing legal employment. The agencies help to match demand and supply and increase the reliability of the service, thus providing further incentives to legalize household help.

\section{MarketContracted Household Work}

Household work, including marketcontracted household work (MCHW), encompasses domestic activities such as cleaning, shopping and childcare, also called "z-goods" (Becker 1993). Housework is an important economic sector whose size and value is frequently underestimated due to its informal nature. Historically, housework in higher income households was partly undertaken by domestic servants. Given the legality of their employment, the number of servants could be readily counted in censuses. With technological progress, rising skills, decreasing income inequalities and changing cultural norms, employment in this part of the domestic employment sector has declined steadily over time. 
For instance, the number of servants per 1,000 inhabitants dropped from 19.8 in 1900 in the Unites States and 31.2 in 1895 in Germany to 15.9 in 1940 in the US and 19.5 in 1933 in Germany (Stigler 1946: 4). From 1929 to 1976, the share of reported domestic employment in total employment in the US dropped from $6.9 \%$ to $2.2 \%$ (Wolff 1985: 316). It is unclear to what extent this drop is the result of an increasing share of household labor being employed illegally. Within households, there are strong gender differences in the distribution of household labor. Data from the United States for 1979 to 1987 shows that on average married couples with full-time jobs spend between 7 hours (husbands) and 20 hours (wives) per week doing housework (Hersch and Stratton 1994: 122).

Using data from the GSOEP, the daily market value of domestically produced housework in Germany in 1992 has been estimated as 72 DM for double income households with no children and 201 DM for a household with one working parents and at least two children (Althammer and Wenzler 1996: 411). In aggregate, estimates of the value of housework as a share of national income range from $20 \%$ to over $40 \%$ in various OECD economies for various years in the twentieth century (Thomas 1992: 24-25).

In contrast to such domestically produced housework, MCHW refers to paid services contracted by private households to substitute for z-goods. Such work is characterized by four aspects:

- There are significant fixed and transaction costs in the organization of MCHW, e.g. for replacement hires or employee holiday arrangements. The fix costs might include trust for employers and employees. The former need to open their homes for household workers while the latter often accept household work without any formal contract.

- MCHW requires only low skills and no formal qualifications. 
- In high-wage countries such as Germany, formal MCHW jobs often imply a high tax wedge between total labor costs and the employee's disposable income (Schneider and Kempe 2002).

- MCHW jobs are frequently informal and short-term work arrangements with a low level of legal protection.

These characteristics of MCHW imply that there are strong incentives not to demand household work in the market but instead to undertake the production of the zgoods with own household labor. In West Germany, for instance, the female labor market participation rose from 50\% in 1968 to only 56.9\% in 1989 which induced an increase in the demand for market-contracted household services (broadly defined) of $5.5 \%$ over that period (Assenmacher and Wenke 1993: 39). This is equivalent to an increase in GDP over that period of $1.2 \%$ as a result of the substitution of non-market household work with marketcontracted household services.

In many other OECD countries, this substitution effect is much larger (Assenmacher and Wenke 1996: 166). In part, this may be explained by household preferences, by the varying availability of child-care facilities (Kreyenfeld and Hank 2000, and van Dijk and Siegers 1996) or by different institutional arrangements of the national labor markets (Hank 2001). Rigidities in the market for MCHW may thus be one of the reasons for the low labor market participation rate of German women.

Alternatively, MCHW may be procured in the shadow or informal economy, thus avoiding the tax wedge (Fortin et al. 2000). MCHW contributes a significant share of the shadow economy, which itself constitutes on average up to $17 \%$ of official gross domestic product in OECD countries (Mummert and Schneider 2001: 289). 
A number of studies have attempted to estimate the extent of legal employment in private households in Germany. (For a survey citing he following estimates, see Schupp 2002.) Private German households hiring domestic help must register the contract with the Federal Employment Agency (Bundesanstalt für Arbeit) where it enters the employee statistics (Beschäftigtenstatistik). On that basis, there were 39,800 legal domestic workers in private households in Germany in June 2000. A further estimate is provided by the Mikrozensus (similar to the CPS from the United States Bureau of Labor Statistics), which accounts for all employment in one week (Lüttinger and Riede 1997). Based on that survey, 137,000 employees worked as their main job (full-time or part-time) in private German households in May 2000. This survey may, however, underestimate part-time work, which would significantly affect the estimate for MCHW. Another estimate derives from the German system of national accounts, which, on an annual basis and taking into account domestically employed cross-border commuters, estimates that in 2000 there were 501,000 employees working in the domestic service sector, broadly defined. This statistic is more likely to account accurately for part-time work than the Mikrozensus estimate.

However, the total employment in private households is likely to exceed these estimates significantly. Two non-gover nmental household surveys have addressed this issue. For 1997, a survey of social security exempted employees estimated the size of the MCHW sector at 1.1 million persons. This is equivalent to $20 \%$ of all social security exempted employees in Germany that year. Domestic work is the main job for most employees in this sector, with only $12 \%$ of all domestic workers having a primary job in a different sector.

Quite uniquely, the GSOEP asked respondents directly if they employed domestic help, deliberately skirting the issue of the legality of the employment contract and thus forming a more truthful representation of the size of the MCHW-sector in Germany. Given that 
participation in the GSOEP is voluntary and anonymous, the truthfulness and hence the quality of the responses is expected to be high. The GSOEP-data then suggests that 4.35 million households employed domestic workers in 2000 which represents $11.3 \%$ of all German households. This compares with $11.2 \%$ of all households hiring help in 1994 and 10.4\% in 1991 (Schupp 2001: 206).

A similar but less comprehensive survey of the United States found that $17 \%$ of all householders aged 18 and above in the US at least occasionally pay someone to do housecleaning (Dortch 1996: 9). However, no reference period nor the legal status of this employment were clarified in the survey. An additional $8 \%$ of all householders stated that they paid only very rarely for some household cleaning. Therefore, up to a quarter of all adult Americans can be said to have hired help of any legal status in their home at some point in the mid-1990s.

These data demonstrate that households in Germany and the US have a high demand for household services. In the future, this is likely to rise further as disposable income increases, the share of pensioners in the population grows, the institutional provision of childcare facilities remains insufficient, women's qualifications rise, the female participate rate in Germany increases from its still low level, the dis-incentives for women to work in the tax, social security, healthcare and benefits systems decline and as the reservation wage of the unemployed diminishes.

On the labor supply side, GSOEP data shows that there are at least 100,000 unemployed and social security claimants with relevant training and work experience for employment in the sector for MCHW (Brück et al. 2002: 365). Depending on the method of estimation, there are another 1.9 million economically inactive and low skilled adults in Germany, mainly 
housewives, which could also work in this sector. These dimensions suggest that it should be possible to satisfy additional demand for MCHW from among the unemployed or economically inactive population in Germany.

\section{Literature Review}

Hank (2001) analyzed the labor supply decisions of German woman given the presence of MCHW using a sample of GSOEP data from 1994. His sample was restricted to West German partner households where the female partner was aged 25 to 55 years resulting in a sample size of 1,386 households. The study does not account for regional price differences in the cost of MCHW but does control for the educational achievement of the employers. The paper confirms inter alia that income, the presence of children in the household and larger dwellings have positive effects on the decsion to hire domestic help. However, the effects of the income variable are quite weak. At the mean, monthly net household income (excluding the woman's wage) has to rise by $26 \%$ to raise the probability of hiring domestic help by one percentage point.

A study of the demand for live-in servants and the female labor supply in Hong Kong confirms the importance of household income and the presence of young children for the demand for MCHW (Suen 1994). However, the demand for live-in servants does not appear to be dependent on life-cycle effects. This may be the result of the consideration for casual and possibly illegal MCHW, which is more likely to be demanded at different intensities throughout the life cycle.

Early work on household expenditure for domestic servants confirms the importance of household income and servants' wages for the demand of domestic labor (Stigler, 1946: 32). The income elasticity of demand for servants by American families in 1935-36 varies 
between 2.13 for households earning 2,500 to 5,000 US Dollar a year and 1.36 for households earning 4,000 to 10,000 US Dollar a year. These rates are among the highest estimated for that period and are roughly twice as large as the income elasticities of demand for clothing or transportation. The price elasticity of the demand for servants, which was estimated at -2.3 , further confirms that MCHW in the 1930s in the US was extremely responsive to household income.

On the other hand, a time-series estimate of the demand for domestic servants in the United States from 1947 to 1976 suggests that mean household income has no significant effect on the demand for servants (Wolff 1985: 325). The author hypothesizes that domestic servants are a luxury good and that hence the income distribution, not the mean household income, should determine demand. While this hypothesis remains untested, the empirical finding from that paper is consistent with our results as we address more casual and informal forms of MCHW.

\section{Household Work Agencies and Wage Subsidies}

The high fix and transaction costs of employing domestic workers can be reduced in principle by household work agencies. Such agencies can facilitate market clearing by bundling the labor demand of many households each interested in hiring a few hours of labor each week. Such bundling also reduces the hiring costs per household. In addition, such agencies can arrange substitute workers during holiday or sick leave and carry out background checks on workers to reduce the risks associated with opening the private home to workers.

Workers can benefit from being employed by such agencies as they would work in legally recognized jobs with social security and pension rights. This is particularly attractive for low skilled workers with few alternative employment opportunitie s in Germany. At the same time, 
agencies could help improve the productivity and the long-term employability of their employees by offering training opportunities, for example in coordination with local employment centers.

An example of similar agencies are the home-care agencies established in the mid-1990s by the last administration of chancellor Kohl, when an obligatory care insurance was introduced in Germany which provides for mobile home care or residential care for the aged and disabled. These agencies might expand their scope by also offering subsided MCHW in the future.

In practice, MCHW agencies exist in Germany as part of subsidized trials to support the development of this business sector. A survey of various household work agencies conducted in October 1998 identified a total of 84 agencies, most of these in West Germany (Bittner and Weinkopf 2000, and Weinkopf 2002). On average, each of the agencies employed 14 domestic workers and 2 employees in management roles. Each employee worked on average for 4.6 customers.

Households paid an average wage of 23.26 DM/hour. Employees earned an average pre-tax wage of 15.29 DM/hour including periods of holiday and illness, which equals a post-tax income of $10.42 \mathrm{DM} /$ hour for a single earner. This compares with a minimum wage of 10.74 DM/hour for a domestic household help in West Germany in 2002, which in turn equals a post-tax income of $8.41 \mathrm{DM} /$ hour for a single earner (where 1 Euro equals $1.95633 \mathrm{DM}$, Federal Ministry of Finance 2003, and WSI Tarifarchiv 2002). The tax wedge in Germany for single low income earners in this period thus ranges from $22 \%$ to $32 \%$.

Three quarters of these agencies received general government subsidies, lasting on average over two years, while almost all agencies received wage subsidies for some employees. Given 
the high non-wage labor costs, the additional costs of managing the agencies and the low risk and costs of detection of illegal MCHW, no legal and unsubsidized market for MCHW provided through household work agencies appears feasible in Germany.

In the United States, professional home cleaning companies exist but their market share, relative to all cleaning being undertaken in the US, is quite small. Based on household survey results, about $8 \%$ of all US households hired a maid or a housekeeper in 1996, up from $6 \%$ in 1986, while only 2\% demanded a professional household work agency in both 1986 and 1996 (Dortch 1996: 4, 7).

The survey results from the US and Germany that many more people hire a household help directly than to purchase household services through an agency suggest that the benefits of the household work agencies do not outweigh the costs of legalizing and bundling MCHW. Some explanations for this observation might be the high marginal tax rates and marginal health care costs for married women resuming work, the high total labor costs incurred by the agencies when legalizing MCHW, and the low risks of detection associated with illegal MCHW for employees and employers.

In view of these obstacles to legal MCHW, policy initiatives in Germany aim to establish MCHW agencies and to subsidize MCHW to overcome market coordination problems and the tax wedge. For instance, the German state of Rhineland-Palatia started a parliamentary initiative in the upper chamber of the federal parliament in 2001 suggesting such a package of measures (Brück et al., 2002, and Bundesrat 2001). The bill would enable agencies or private households to hire domestic workers and to receive wage subsidies of up to $50 \%$ of the wage costs. Such subsidy has the advantage of benefiting also non-wage earning households such as pensioners, who demand a large share of MCHW in Germany. The parliamentary initiative 
ultimately failed but the likely consequences of such a proposal are assessed below in more detail.

\section{The Model}

We model the demand for MCHW as a function of household income, the relative price of market-contracted domestic labor, household composition, dwelling size and the need for domestic care. These are also standard determinants of labor demand in other sectors (Hamermesh 1993), of the female labor supply (Killingsworth 1986), of intra-household time allocation decisions (Gronau 1986) and of household life-cycle decisions (Rosenzweig and Wolpin 1980). Other studies of the demand for MCHW have estimated similar models (Hank 2001, and Suen 1994). A descriptive analysis of the demand for formal MCHW in the United States found similar variables to be important (Dortch 1996).

Of these variables, the ratio of monthly household net income to the hourly wage rate (price) of MCHW, or hereafter "relative income", is our key explanatory variable for the demand for household services. By increasing this measure by, say, $x \%$ in our demand equation, we can simulate a policy-driven subsidy of household services of $x \%$ magnitude.

Note that we do not consider the intra-household allocation of income or time. While such an approach would be constructive for the analysis of the total demand for household work or the division of household work between home- and market-production, we are only concerned with the responsiveness of a household's demand for one type of marketcontracted service. It is hence the household's total income (or its aggregate or average comparative advantage) plus some measures for household composition that determine its demand for MCHW.

We use three specifications, whereby the demand for MCHW is a function of: 
- the relative income, the household composition, the number of rooms, and the presence of an invalid in the household;

- the above variables plus a quadratic in the relative income to price;

- the above variables plus the age of the household head as a quadratic.

Further, for policy purposes, we simulate various levels of the relative income between $10 \%$ and $50 \%$ above the estimated mean, where these changes are equivalent to income subsidies for the employers (householders) with values between $10 \%$ and $50 \%$ of total MCHW labor costs. We posit that as the relative income increases, one should observe additional demand. We further assume that employers are exempt from value -added taxes and from employers' social security contributions.

\section{Data and Methods}

The GSOEP is an ongoing representative household panel data set from 1984 to the present, consisting of some 24,000 individuals and roughly 12,000 households living in West and East Germany (Wagner et al., 1993). In this paper, we focus on the question in the 2000 household questionnaire: "Do you employ a cleaning or household help in your household occasionally or regularly?", allowing the three possible responses: "no", "yes, occasionally" and "yes, regularly" (Table 1). The sample size, with 8,738 households from all states within Germany, is nationally representative.

We rely on external information to derive the average hourly wage rate of MCHW per region, as the GSOEP does not have adequately large sample sizes to account for local job markets. This information is derived from the most recent publicly available Mikrozensus data set (Lüttinger and Riede 1997). Based on those individuals in 1997 who stated they worked in the 
"household services" sector, an hourly wage for each of the 16 states was calculated, serving a indicator for the local price of MCHW. We then calculate net household income relative to the price of household services, the regressor "relative income".

We include extensive control variables for the composition of the household from the household roster, namely single-person households, couples, single parents, couples with young children, couples with older children, couples with young and old children, multigenerational households, and other households. The variables used in the regression analysis are defined and summarized in Table 2.

The presence of young children and older persons in multi-generational households are expected to raise the demand for household services. In the GSOEP the number of rooms in the dwelling and whether there are persons in the household requiring long-term care ("invalids" to any degree) are directly asked. Both aspects are expected to increase demand for MCHW. The age of the household head is expected to be positively correlated with household services demand and is also included as a control variable.

To analyze the demand for MCHW, we estimate an ordered probit specification (Greene 2003) with the three above mentioned possible outcomes using Stata. We also calculate the marginal effects for all possible dependent variable outcomes, based on changes of the explanatory variables.

\section{Results}

We first estimate the linear specification and find that the household struc ture clearly plays an important role in the demand for household services, with all coefficients on household composition being significant (Table 3), with a McKelvey-Zavoina (MZ) pseudo- $\mathrm{R}^{2}$ of 0.2532 (Veall and Zimmermann 1992). Single person households have significantly higher 
demand for cleaning services compared to all other household types (15\%-20\% more likely), perhaps reflecting time constraints and preferences for leisure time. Having a household member requiring permanent care such as an older or handicapped person (so-called "invalids") dramatically increases the demand for MCHW (38\% more likely). Additional number of rooms in a household (and therefore surface area to clean) has a marginal effect of $2 \%$ per room.

The key variable, relative income, is highly significant and has a positive coefficient. For a one percent increase in relative income, the demand for "occasional" MCHW rises by 0.03 percentage points while the demand for "regular" MCHW rises by 0.05 percentage points. Correspondingly, the demand for "no" MCHW drops by 0.08 percentage points. This represents a strong response of households to changes in the wage of domestic workers and of the household's own income.

To allow for non-linearities in relative income, we estimate the extended model and report the results in Table 4 . The coefficients and the significance of the control variables do not change much while the relative income variables are now individually and jointly significant. The MZ pseudo- $\mathrm{R}^{2}$ is 0.2677 . The quadratic specification indicates that a higher relative income increases the demand for MCHW but that effect diminishes with rising income.

This confirms the casual inspection of the data, which indicates that all income deciles have a significant demand for MCHW but that this demand rises at an increasing rate for higher income deciles. In fact, in the first seven deciles $6.6 \%$ of all households demand some MCHW, in the eight and ninth deciles $9.5 \%$ of all households demand some MCHW and in the highest income decile $25 \%$ of all households demand some MCHW (Table 1).

We augment this specification in the full model with the age of the household head as a 
quadratic expression, and find that these terms are jointly significant (Table 5), with an MZ pseudo- $\mathrm{R}^{2}$ of 0.3459 . In fact, households with older heads have less demand for MCHW but this effect diminishes for households with very old heads. In regard to the base model, the coefficients of the control variables indicating the presence of younger children stay significant but are less negative. This indicates that having children and having a younger head of household are correlated, as would be expected. Likewise, in the full model the coefficient of the invalid variable drops as the presence of an invalid also becomes more probable with an older household head. The relative income variables are again significant and suggest diminishing effects of relative income on demand at high relative incomes.

These results correspond to the Hank (2001) study of the demand for MCHW using a sample of GSOEP data from 1994. In contrast to our results, the age variable and its square are individually insignificant in that analysis as are the variable indicating the presence of a person needing care. These results may derive from the narrow definition of the sample, excluding many households of retired couples or individuals. The significance and positive coefficient of the categorical variable "university degree" in Hank's regression may simply represent the income effect also captured by the income variable, as better educated persons do not necessarily have a higher preference for domestic household services per se.

By explicitly considering casual and informal forms of household labor, we demonstrate that changing relative income has strong effects on the demand for MCHW. We believe this is the first empirical estimate indicating that domestic employment in the shadow economy is a normal good with a high price elasticity of demand.

Relative income is increased in the policy simulations through subsidies ranging from $10 \%$ to $50 \%$. The magnitude of the marginal effects is non-linear as reported in Table 3. For 
simulation purposes, the number of total households in Germany is then multiplied by the three marginal effects "no", "yes, occasionally" and "yes, regularly", providing absolute numbers of household additionally demanding MCHW. For example, the model suggests that a $10 \%$ subsidy induces 281,683 more households to demand MCHW to some degree (“occasionally" and "regularly" combined), whereas a 20\% subsidy results in 594,083 more households demanding MCHW. The 50\% subsidy would induce additional demand for MCHW in 1,728,874 households.

In the extended model, the quadratic term for relative income is significant, so the entire quadratic expression is used to calculate the marginal effect of relative income on household cleaning demand. Here we obtain only 206,349 more households for a $10 \%$ subsidy but 597,160 more households for a $20 \%$ subsidy, back up to the level of the basic model, and 1,982,136 more house holds for a 50\% subsidy (Table 4).

In the full model, the impact of the $10 \%$ subsidy is lowered to 177,771 households but the impact of the $20 \%$ subsidy rises to 615,058 households (Table 5). With a 50\% subsidy, the full model predicts demand for MCHW rising by 2,231,619 households. Figure 1 illustrates the effects of subsidizing the demand for household services, combining all model specifications. The models, therefore, do not differ substantially in their policy effects but the quadratic specifications gemerally predict a larger demand effect at higher subsidy levels than the basic, linear model.

\section{Policy Implications}

The political motivation for subsidizing low skilled but market-contracted jobs in private households is twofold. First, it is seen as a chance to reduce the dramatic unemployment of the low skilled in Germany. Second, it could contribute to the reduction of black market 
activity, which has strong fiscal implications as income earned in the shadow economy is often also spend in the shadow economy (Fortin et al. 2000).

Our findings show that subsiding the demand for low-skilled jobs can have significant quantitative effects. A small subsidy of $10 \%$ of wage costs can create more than 175,000 work places. Assuming that work agencies can bundle four households into one full-time job, this represents over 44,000 new and legal full-time jobs. For the highest-simulated age subsidy, over 550,000 new jobs may be created. These figures demonstrate that households react strongly to price incentives. Furthermore, the responsiveness increases with the level of the subsidy. This results from the fact that at higher subsidy levels, the demand for MCHW is increasingly attractive for families with many children or households with pensioners, which have relatively low per capita incomes but a high demand for domestic help.

The estimated costs of the wage subsidies are quite low if the subsides jobs are filled with previously unemployed persons. Assuming that only full-time jobs are offered by the agencies, we calculate that a $10 \%$ subsidy costs 1.7 billion euro and a $50 \%$ subsidy 12.2 billion euro per annum. However, the value of the reductions in social security payments and in new income tax and social security revenue is 1.4 billion euro and 8.8 billion euro per annum leaving net costs to the government of between 0.3 billion euro and 3.4 billion euro per annum, respectively. This is equivalent to net fiscal costs of 3,412 euro per full-time job per annum for the $10 \%$ subsidy and 6,177 euro per full-time job per annum for the 50\% subsidy.

The costs rise exponentially with the rate of subsidy as increased subsidies increasingly benefit existing and already subsidized jobs. It is important to note that these jobs are offered by household work agencies and hence are full-time jobs which require the employees to pay 
the usual income taxes and social security benefits. It is through the agencies that standard work contracts with the usual tax and benefit framework can be offered. In addition, full-time jobs may have the benefit of reducing the incentive of employees to engage in shadow activities, unlike for unemployed or part-time employees.

These calculations exclude the social and fiscal benefits derived from a higher compliance with tax and employment legislation, which also include reduced participation in further shadow market activities by illegal domestic workers. In addition, the benefits associated with a higher labor market participation rate especially by more educated wives and mothers have also been excluded here (Ghosh and Lien 2002). The estimates of the fiscal costs of the wage subsidy hence represent an upper limit.

In contrast to this direct wage subsidy, offering tax breaks to private employers may be less effective as these benefit mainly high wage earners wit h high marginal income tax rates. For this reason the German law commonly known as the "parlor maid privilege", which was in effect from 1997 to 2001, failed to register much interest, as the above-cited data on formally registered MCHW demonstrates (Schupp 2001).

Given the much higher unemployment for the unskilled in East Germany, it would seem desirable to create many of the new jobs in East Germany. However, the demand for MCHW is much stronger in West Germany than in East Germany, even controlling for income differentials. This suggests that either that the reservation wage, in the form of the unemployment benefits, is too high in East Germany or that East Germans for cultural reasons are less inclined to demand MCHW. Given the low social prestige of MCHW in Germany and the strong East German tradition of celebrating skilled labor and rejecting so-called exploitative work practices, this latter interpretation does not seem unreasonable. Whatever 
the reason, subsidizing $\mathrm{MCHW}$ is no short-cut for lowering the massive unemployment rates of the unskilled in East Germany.

\section{Conclusions}

The German labor market paradox of high unemployment for the low skilled and a low degree of production specialization especially by high skilled women derives in part from the high non-wage costs of domestic labor and from the coordination problem of part-time domestic labor. We address these issues by estimating the demand for employment of shadow market-contracted household work using a unique data source.

The results of the empirical analysis imply that labor demand in this sector is very price elastic. Cutting the non-wage costs of MCHW and establishing household work agencies strongly increase the demand for such labor, even for lower income households. Our policy proposal is hence one option for reducing the incentives for employers and employees to engage in shadow economy transactions.

Our proposal will not overcome the massive structural problems of the German labor market. In the long-term, policy measures should address the skills shortage experienced by a large share of the population and the level of non-wage labor costs. In the shortterm, however, subsiding the legal employment of MCHW in private homes is a cost-effective way to create new jobs. The measure would partic ularly benefit the low skilled who suffer from the highest unemployment rates in Germany. The low formal qualifications required of domestic workers suggest that an expansion of this sector may also help to reduce the high unemployment rates experienced in other European economies for low skill workers.

Further policies which could enhance the effectiveness of the proposal but which we did not evaluate in our analysis include raising the costs and the chance of detection of illegal 
domestic employment. In addition, legalizing illegal residents and opening the European single market for immigrants from the EU-accession countries sooner than currently planned would increase the incentives to report domestic work practices to the tax authorities.

In evaluating our high estimate of the income elasticity of domestic labor demand it is important to bear in mind that the sector for MCHW is a well-defined and unique economic sector. The effectiveness of the wage subsidies in this sector is larger than that of most other sectors as the leakage of subsidies to existing employment is much lower. The analysis of illegal behavior and the responsiveness of market participants to attempts at legalizing such behavior makes this sector, and this study, distinct. 
Table 1: Demand for Market-Contracted Household Work by Income Deciles

\begin{tabular}{|c|c|c|c|c|c|}
\hline \multirow{2}{*}{$\begin{array}{l}\text { Deciles of Net } \\
\text { Household Income }\end{array}$} & & \multicolumn{3}{|c|}{ Use Household Services } & \multirow[b]{2}{*}{ Total } \\
\hline & & No & Yes, Occasionally & Yes, Regularly & \\
\hline \multirow[t]{2}{*}{1} & $\mathrm{n}$ & $3,367,066$ & 73,784 & 134,701 & $3,575,551$ \\
\hline & $\%$ & 94.17 & 2.06 & 3.77 & 100.00 \\
\hline \multirow[t]{2}{*}{2} & $\mathrm{n}$ & $2,838,151$ & 96,838 & 147,802 & $3,082,791$ \\
\hline & $\%$ & 92.06 & 3.14 & 4.79 & 100.00 \\
\hline \multirow[t]{2}{*}{3} & $\mathrm{n}$ & $3,452,548$ & 145,559 & 119,297 & $3,717,404$ \\
\hline & $\%$ & 92.88 & 3.92 & 3.21 & 100.00 \\
\hline \multirow[t]{2}{*}{4} & $\mathrm{n}$ & $3,932,867$ & 74,061 & 139,236 & $4,146,164$ \\
\hline & $\%$ & 94.86 & 1.79 & 3.36 & 100.00 \\
\hline \multirow[t]{2}{*}{5} & $\mathrm{n}$ & $1,819,425$ & 56,520 & 88,577 & $1,964,522$ \\
\hline & $\%$ & 92.61 & 2.88 & 4.51 & 100.00 \\
\hline \multirow[t]{2}{*}{6} & $\mathrm{n}$ & $4,255,490$ & 110,215 & 182,424 & $4,548,129$ \\
\hline & $\%$ & 93.57 & 2.42 & 4.01 & 100.00 \\
\hline \multirow[t]{2}{*}{7} & $n$ & $2,178,537$ & 68,626 & 78,570 & $2,325,733$ \\
\hline & $\%$ & 93.67 & 2.95 & 3.38 & 100.00 \\
\hline \multirow[t]{2}{*}{8} & $\mathrm{n}$ & $2,701,154$ & 111,218 & 174,450 & $2,986,822$ \\
\hline & $\%$ & 90.44 & 3.72 & 5.84 & 100.00 \\
\hline \multirow[t]{2}{*}{9} & $\mathrm{n}$ & $2,928,160$ & 116,976 & 190,907 & $3,236,043$ \\
\hline & $\%$ & 90.49 & 3.61 & 5.90 & 100.00 \\
\hline \multirow[t]{2}{*}{10} & $\mathrm{n}$ & $2,420,493$ & 220,117 & 587,212 & $3,227,822$ \\
\hline & $\%$ & 74.99 & 6.82 & 18.19 & 100.00 \\
\hline \multirow[t]{2}{*}{ Total } & $\mathrm{n}$ & $29,893,891$ & 1073914 & 1843176 & $32,810,981$ \\
\hline & $\%$ & 91.11 & 3.27 & 5.62 & 100.00 \\
\hline
\end{tabular}


Table 2: Summary Statistics

\begin{tabular}{|c|c|c|c|c|c|}
\hline Variable & Obs & Mean & Std. Dev. & Min & $\overline{\operatorname{Max}}$ \\
\hline Use Household Services & 11539 & 0.145 & 0.486 & 0 & 2 \\
\hline Single Person Household & 11539 & $0.36 r$ & 0.481 & 0 & 1 \\
\hline Couple, No Children & 11539 & 0.291 & 0.454 & 0 & 1 \\
\hline Single Parent with Children & 11539 & $0.05 \varepsilon$ & 0.222 & 0 & 1 \\
\hline Couple with Young Children & 11539 & 0.165 & 0.371 & 0 & 1 \\
\hline Couple with Old Children & 11539 & $0.07 \varepsilon$ & $0.26 \subseteq$ & 0 & 1 \\
\hline Couple with Young and Old Children & 11539 & $0.03 \varepsilon$ & 0.175 & 0 & 1 \\
\hline Multiple Generation Household & 11539 & $0.00 \leqq$ & 0.093 & 0 & 1 \\
\hline Other Household & 11539 & $0.01 \varepsilon$ & $0.11 C$ & 0 & 1 \\
\hline Invalid in Household & 11539 & $0.03 \varsigma$ & 0.193 & 0 & 1 \\
\hline Number of Rooms & 11539 & 3.624 & 1.695 & 1 & 15 \\
\hline Age of Household Head & 11539 & $51.2 \overline{1}$ & $17.1 \varepsilon$ & 17 & 90 \\
\hline Relative Income & 11539 & $140.3 C$ & 85.31 & 12.53 & 1102.4 \\
\hline
\end{tabular}


Table 3: Demand for Market-Contracted Household Work: Relative Income

\begin{tabular}{|c|c|c|c|c|c|}
\hline Variable & Coefficient & t-Value & $\Delta$ None & $\Delta$ Occasional & $\Delta$ Regular \\
\hline cut1 & 2.12396 & - & -- & -- & $\overline{--}$ \\
\hline _cut2 & 2.41994 & -- & -- & -- & -- \\
\hline Observed Baseline & - & - & 0.8978 & 0.0371 & 0.0651 \\
\hline Single Person Household & $-\cdot$ & -- & -- & -- & -- \\
\hline Couple, No Children & -0.86464 & -11.46 & 0.1616 & -0.0519 & -0.1097 \\
\hline Single Parent with Children & $-0.7708 \mathrm{C}$ & -6.36 & 0.1517 & -0.0479 & -0.1038 \\
\hline Couple with Young Children & $-1.0383 \gtrsim$ & -7.21 & 0.1762 & -0.0583 & -0.1180 \\
\hline Couple with Old Children & $-1.5614 \approx$ & -12.77 & 0.1996 & -0.0694 & -0.1301 \\
\hline Couple with Young and Old Children & -1.43464 & -9.78 & 0.1960 & -0.0676 & -0.1284 \\
\hline Multiple Generation Household & $-1.8899 \varepsilon$ & -7.81 & 0.2049 & -0.0724 & -0.1326 \\
\hline Other Household & $-1.5476 \varepsilon$ & -5.20 & 0.1992 & -0.0693 & -0.1300 \\
\hline Invalid in Household & $1.3762 \varepsilon$ & 14.37 & -0.3793 & 0.0832 & 0.2961 \\
\hline Number of Rooms & $0.1412 \varepsilon$ & 9.28 & -0.0212 & 0.0078 & 0.0135 \\
\hline Age of Household Head & -- & -- & -- & -- & -- \\
\hline (Age of Household Head)2 & -- & -- & -- & -- & -- \\
\hline Relative Income & 0.00565 & 11.58 & -0.0008 & 0.0003 & 0.0005 \\
\hline$(\text { Relative Income })^{2}$ & -- & - & -- & -- & -- \\
\hline \multicolumn{6}{|l|}{ Simulation Marginal } \\
\hline $10 \%$ Subsidy & -- & - & -0.0106 & 0.0040 & 0.0067 \\
\hline $20 \%$ Subsidy & -- & -- & -0.0224 & 0.0082 & 0.0142 \\
\hline $30 \%$ Subsidy & -- & - & -0.0355 & 0.0127 & 0.0228 \\
\hline $40 \%$ Subsidy & -- & - & -0.0497 & 0.0174 & 0.0323 \\
\hline $50 \%$ Subsidy & -- & - & -0.0653 & 0.0223 & 0.0430 \\
\hline \multicolumn{6}{|l|}{ Additional Household Demand } \\
\hline $10 \%$ Subsidy & -- & - & $-281,683$ & 105,137 & 176,546 \\
\hline $20 \%$ Subsidy & -- & - & $-594,083$ & 217,389 & 376,694 \\
\hline $30 \%$ Subsidy & -- & - & $-938,646$ & 336,292 & 602,353 \\
\hline $40 \%$ Subsidy & -- & - & $-1,316,591$ & 461,216 & 855,375 \\
\hline $50 \%$ Subsidy & -- & -- & $-1,728,874$ & 591,357 & $1,137,517$ \\
\hline $\begin{array}{l}\text { Note: Ordered probit estimation, own } \\
\text { Use household cleaning services ? } 0 \\
\mathrm{~N}=8738 \text {, Wald } \mathrm{X}^{2} \text { Test (10) is } 516.4 \mathrm{n} \\
\end{array}$ & $\begin{array}{l}\text { using Germ } \\
\text { occasionally } \\
.00 \text {, and } \mathrm{MZ} \\
\end{array}$ & $\begin{array}{l}\text { "Yes, } r \\
2 \text { "Yconc }\end{array}$ & $\begin{array}{l}\text { Panel } 2000 \\
\text { larly" }\end{array}$ & & \\
\hline
\end{tabular}


Table 4: Demand for Market-Contracted Household Work: Relative Income Quadratic

\begin{tabular}{|c|c|c|c|c|c|}
\hline Variable & Coefficient & t-Value & $\Delta$ None & $\Delta$ Occasional & $\Delta$ Regular \\
\hline cut1 & $2.3520 \mathrm{c}$ & - & -- & -- & $\overline{--}$ \\
\hline _cut2 & 2.64925 & -- & -- & -- & -- \\
\hline Observed Baseline & - & - & 0.8978 & 0.0371 & 0.0651 \\
\hline Single Person Household & $-\cdot$ & -- & -- & -- & -- \\
\hline Couple, No Children & $-0.9505 C$ & -12.08 & 0.1773 & -0.0567 & -0.1205 \\
\hline Single Parent with Children & -0.81621 & -6.49 & 0.1637 & -0.0511 & -0.1126 \\
\hline Couple with Young Children & -1.13502 & -7.80 & 0.1915 & -0.0630 & -0.1285 \\
\hline Couple with Old Children & $-1.6515 \varepsilon$ & $-13.6 €$ & 0.2120 & -0.0730 & -0.1389 \\
\hline Couple with Young and Old Children & $-1.5259 ?$ & $-10.4 \mathrm{C}$ & 0.2089 & -0.0714 & -0.1375 \\
\hline Multiple Generation Household & $-1.9879 €$ & -8.33 & 0.2168 & -0.0757 & -0.1411 \\
\hline Other Household & -1.64747 & -5.43 & 0.2119 & -0.0730 & -0.1389 \\
\hline Invalid in Household & 1.39877 & 14.46 & -0.3836 & 0.0845 & 0.2991 \\
\hline Number of Rooms & $0.1349 \approx$ & 8.99 & -0.0197 & 0.0073 & 0.0124 \\
\hline Age of Household Head & -- & -- & -- & -- & -- \\
\hline (Age of Household Head)2 & -- & -- & -- & -- & -- \\
\hline Relative Income & $0.0090 \subseteq$ & 8.69 & 0.0046 & -0.0017 & -0.0028 \\
\hline (Relative Income) $)^{2}$ & -0.00001 & -3.63 & -- & -- & -- \\
\hline \multicolumn{6}{|l|}{ Simulation Marginal } \\
\hline $10 \%$ Subsidy & -- & - & -0.0078 & 0.0029 & 0.0049 \\
\hline $20 \%$ Subsidy & -- & -- & -0.0226 & 0.0082 & 0.0144 \\
\hline $30 \%$ Subsidy & -- & - & -0.0387 & 0.0137 & 0.0250 \\
\hline $40 \%$ Subsidy & -- & - & -0.0562 & 0.0193 & 0.0369 \\
\hline $50 \%$ Subsidy & -- & - & -0.0749 & 0.0251 & 0.0498 \\
\hline \multicolumn{6}{|l|}{ Additional Household Demand } \\
\hline $10 \%$ Subsidy & -- & - & $-206,349$ & 76,758 & 129,591 \\
\hline $20 \%$ Subsidy & -- & - & $-597,160$ & 216,747 & 380,413 \\
\hline $30 \%$ Subsidy & -- & - & $-1,024,829$ & 362,492 & 662,337 \\
\hline $40 \%$ Subsidy & -- & - & $-1,487,382$ & 512,077 & 975,305 \\
\hline $50 \%$ Subsidy & -- & -- & $-1,982,136$ & 663,490 & $1,318,646$ \\
\hline $\begin{array}{l}\text { Note: Ordered probit estimation, own } \\
\text { Use household cleaning services ? } 0 \\
\mathrm{~N}=8738 \text {, Wald } \mathrm{X}^{2} \text { Test (11) is } 529.3 \mathrm{u} \\
\end{array}$ & $\begin{array}{l}\text { using Germe } \\
\text { occasionally } \\
.00 \text {, and MZ }\end{array}$ & $\begin{array}{l}\text { "Yes, } r \\
2 \text { "Yconc }\end{array}$ & $\begin{array}{l}\text { Panel } 2000 \\
\text { larly" }\end{array}$ & & \\
\hline
\end{tabular}


Table 5: Demand for Market-Contracted Household Work: Full Model

\begin{tabular}{|c|c|c|c|c|c|}
\hline Variable & Coefficient & t-Value & $\Delta$ None & $\Delta$ Occasional & $\Delta$ Regular \\
\hline _cut1 & 2.90154 & - & -- & -- & -- \\
\hline _cut2 & 3.22274 & -- & -- & -- & -- \\
\hline Observed Baseline & -. & - & 0.8978 & 0.0371 & 0.0651 \\
\hline Single Person Household & -- & - & -- & -- & -- \\
\hline Couple, No Children & $-0.9282 c$ & -11.43 & 0.1307 & -0.0505 & -0.0802 \\
\hline Single Parent with Children & $-0.5672 \varepsilon$ & -3.87 & 0.0994 & -0.0363 & -0.0632 \\
\hline Couple with Young Children & -0.65854 & -4.35 & 0.1093 & -0.0405 & -0.0687 \\
\hline Couple with Old Children & $-1.4875 C$ & -11.72 & 0.1510 & -0.0611 & -0.0898 \\
\hline Couple with Young and Old Children & -1.16827 & -7.92 & 0.1424 & -0.0565 & -0.0860 \\
\hline Multiple Generation Household & -1.65354 & -6.57 & 0.1534 & -0.0625 & -0.0908 \\
\hline Other Household & $-1.3539 \approx$ & -4.88 & 0.1482 & -0.0595 & -0.0886 \\
\hline Invalid in Household & $1.0123 \overline{7}$ & 9.26 & -0.2182 & 0.0686 & 0.1496 \\
\hline Number of Rooms & $0.1102 c$ & 6.76 & -0.0136 & 0.0057 & 0.0079 \\
\hline Age of Household Head & $-0.0207 €$ & -1.85 & -0.0151 & 0.0066 & 0.0085 \\
\hline (Age of Household Head) ${ }^{2}$ & 0.00041 & 4.12 & -- & -- & -- \\
\hline Relative Income & $0.0120 C$ & $10.3 \mathrm{c}$ & 0.0067 & -0.0028 & -0.0039 \\
\hline$(\text { Relative Income })^{2}$ & -0.00001 & -5.22 & -- & -- & -- \\
\hline \multicolumn{6}{|l|}{ Simulation Marginal } \\
\hline $10 \%$ Subsidy & -- & - & -0.0067 & 0.0028 & 0.0039 \\
\hline $20 \%$ Subsidy & -- & - & -0.0232 & 0.0093 & 0.0139 \\
\hline $30 \%$ Subsidy & -- & - & -0.0418 & 0.0163 & 0.0255 \\
\hline $40 \%$ Subsidy & -- & - & -0.0622 & 0.0235 & 0.0387 \\
\hline $50 \%$ Subsidy & -- & - & -0.0843 & 0.0308 & 0.0535 \\
\hline \multicolumn{6}{|l|}{ Additional Household Demand } \\
\hline $10 \%$ Subsidy & -- & -- & $-177,771$ & 73,383 & 104,388 \\
\hline $20 \%$ Subsidy & -- & -- & $-615,058$ & 246,917 & 368,141 \\
\hline $30 \%$ Subsidy & -- & - & $-1,105,666$ & 430,921 & 674,745 \\
\hline $40 \%$ Subsidy & -- & -- & $-1,646,181$ & 621,876 & $1,024,305$ \\
\hline $50 \%$ Subsidy & $-\cdot$ & - & $-2,231,619$ & 816,001 & $1,415,618$ \\
\hline \multicolumn{6}{|c|}{$\begin{array}{l}\text { Note: Ordered probit estimation, own calculations using German Socio- Econo mic Panel } 2000 \\
\text { Use household cleaning services? } 0 \text { "No", } 1 \text { "Yes, occasionally" and } 2 \text { "Yes, regularly" } \\
\mathrm{N}=8738 \text {, Wald } \mathrm{X}^{2} \text { Test (11) is } 675.6 \text { with pvalue=0.00, MZ pseudo- } \mathrm{R}^{2}=0.3459\end{array}$} \\
\hline
\end{tabular}


Figure 1: Subsidizing Market-Contracted Household Work

Figure 1: Subsidizing Household Cleaning Services

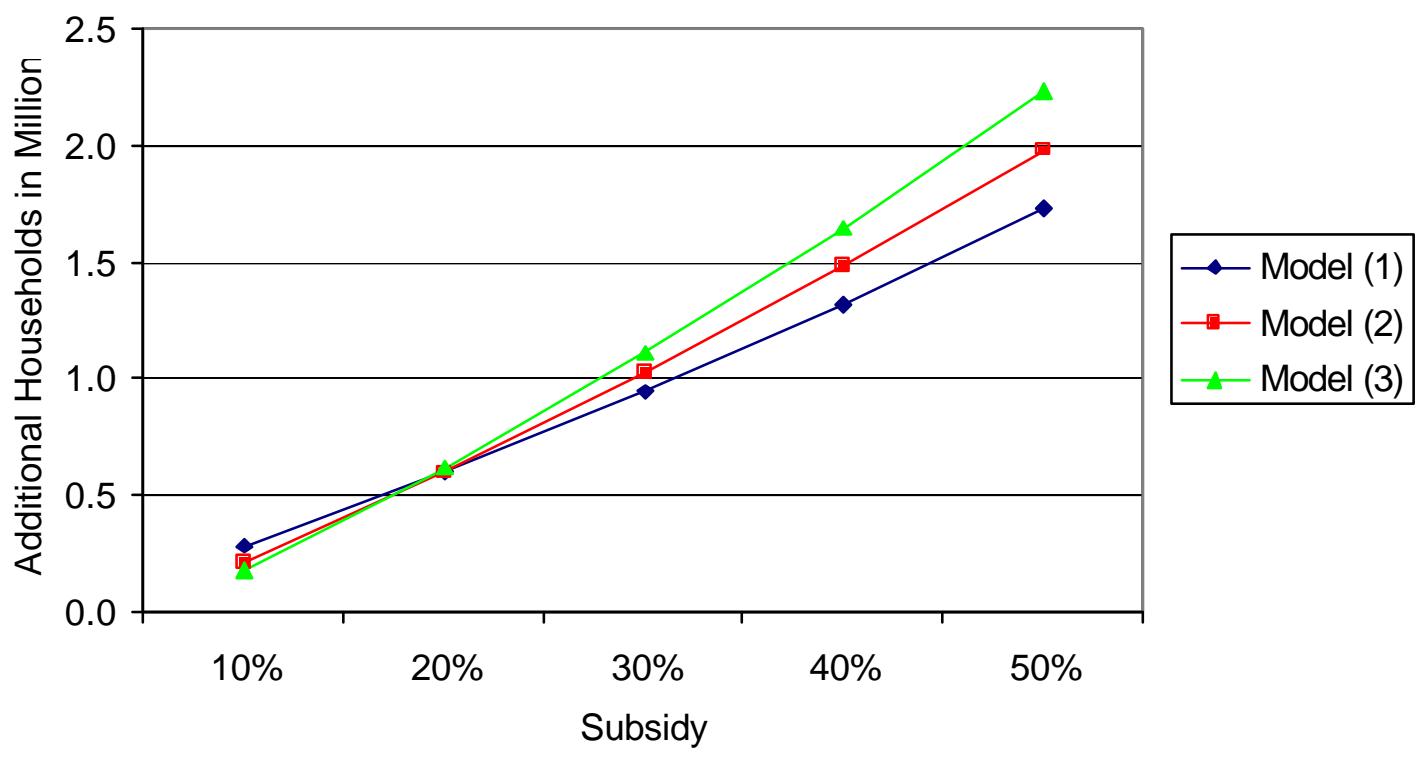




\section{Bibliography}

Althammer, Jorg, and Simone Wenzler. 1996. "Intrafamiliale Zeitallokation, Haushaltsproduktion und Frauenerwerbstätigkeit: Ein mikroökonometrisches Modell zur empirischen Bestimmung des wirtschaftlichen Werts der Hausarbeit." Jahrbücher für Nationalökonomie und Statistik, Vol. 215, No. 4, pp. 398-418.

Assenmacher, Walter, and Martin Wenke. 1993. "Haushaltsproduktion, Frauenerwerbstätigkeit und Dienstleistungsnachfrage privater Haushalte in der Bundesrepublik Deutschland." Jahrbücher für Nationalökonomie und Statistik, Vol. 211, No. 1-2, pp. 22-41.

1996. "Konsumstruktur and Auslagerung von Haushaltsproduktion in ausgewählten Ländern der OECD." Jahrbücher für Nationalökonomie und Statistik, Vol. 215, No. 2, pp. 157-70.

Becker, Gary S. 1993. A Treatise on the Family. Cambridge: Harvard University Press.

Bittner, Susanne, and Claudia Weinkopf. 2000 "Dienstleistungspools am Scheideweg: Erfahrungen und Perspektiven der Förderung haushaltsbezogener Dienste." WSI Mitteilungen, Vol. 53, pp. 256-64.

Brück, Tilman, John Haisken-De New, and Klaus F. Zimmermann. 2002. "Förderung von Agenturen für haushaltsnahe Dienstleistungen schafft Arbeitsplätze für Geringqualifizierte." DIW Wochenbericht No. 23.

Bundesrat. 2001. Gesetzesantrag des Landes Rheinland-Pfalz: Entwurf eines Gesetzes zur Beschäftigungsförderung in Privathaushalten.Bundesrat-Drucksache. Berlin

Dortch, Shannon. 1996. "Maids Clean Up." American Demographics, Vol. 18, pp. 48.

Federal Ministry of Finance. 2003. Berechnungsprogramm zur Lohnsteuer. Berlin.

Fortin, Bernard, Guy Lacroix, and Claude Montmarquette. 2000. "Are Underground Workers More Likely to Be Underground Consumers?" Economic Journal, Vol. 110, pp. 838-60.

Ghosh, Sucharita, and Donald Lien. 2002. "Fertility and Economic Growth: Do Immigrant Maids P lay a Role?" Pacific Economic Review, Vol. 7, No. 2, pp. 245-57.

Greene, William H. 2003. Econometric Analysis. Upper Saddle River: Prentice Hall.

Gronau, Reuben. 1986. "Home Production - a Survey," Orley Ashenfelter and Richard Layard, Handbook of Labor Economics. Amsterdam: North-Holland, pp. 274-304.

Hamermesh, Daniel S. 1993. Labor Demand. Princeton: Princeton University Press.

Hank, Karsten. 2001. "The Employment of Domestic Help and Women's Labor Force Participation in Western Germany." Schmollers Jahrbuch, Vol. 121, No. 1, pp. 105-21.

Hersch, Joni, and Leslie S. Stratton. 1994. "Housework, Wages, and the Division of Housework Time for Employed Spouses." American Economic Review, Vol. 84, No. 2, pp. 120-25.

Killingsworth, Mark R. 1986. "Female Labor Supply: A Survey," James J. Heckman, Orley Ashenfelter, and Richard Layard, Handbook of Labor Economics. Amsterdam: NorthHolland, pp. 103-204.

Kreyenfeld, Michaela, and Karsten Hank. 2000. "Does the Availability of Child Care Influence the Employment of Mothers? Findings from Western Germany." Population 
Research and Policy Review, Vol. 19, No. 4, pp. 317-37.

Lüttinger, Paul, and Thomas Riede. 1997. "Der Mikrozensus: Amtliche Daten für die Sozialforschung." ZUMA-Nachrichten, Vol. 41, pp. 19-43.

Mummert, Anne tte, and Friedrich Schneider. 2001. "The German Shadow Economy: Parted in a United Germany?" Finanzarchiv, Vol. 58, No. 3, pp. 286-316.

Reinberg, Alexander. 1999. "Der qualifikatorische Strukturwandel auf dem deutschen Arbeitsmarkt - Entwicklungen, Perspektiven und Bestimmungsgründe." Mitteilungen aus der Arbeitsmarkt und Berufsforschung, 1999, Vol. 32.

Rosenzweig, Mark R., and Kenneth I. Wolpin. 1980. "Life-Cycle Labor Supply and Fertility: Causal Inferences from Household Models." Journal of Political Economy, Vol. 88, No. 2, pp. 328-48.

Schneider, Hilmar, and Wolfram Kempe. 2002. "Lohnabstandsgebot kein hinreichendes Kriterium für positive Arbeitsanreize im Niedriglohnbereich." Wirtschaft im Wandel, Vol. 8, No. 4, pp. 85-91.

Schupp, Jürgen. 2001. "Private Haushalte als Arbeitgeber bleiben beschäftigungspolitisch von geringer Bedeutung - "Hausmädchenprivileg" überflüssig." DIW Wochenbericht, No. 13, pp. 201-210.

_. 2002. "Quantitative Verbreitung von Erwerbstätigkeit in privaten Haushalten Deutschlands." DIW Materialien, No. 11.

Stigler, George J. 1946. Domestic Servants in the United States 1900-1940. New York: National Bureau of Economic Research.

Suen, Wing. 1994. "Market-Procured Housework: The Demand for Domestic Servants and Female Labor Supply." Labour Economics, Vol. 1, No. 3-4, pp. 289-302.

Thomas, James J. 1992. Informal Economic Activity. Ann Arbor: University of Michigan Press.

van Dijk, Liset, and Jacques J. Siegers, "The Effect of the Supply of Subsidized Day-Care Facilities on Female Labour Supply." Labour, Vol. 10, No. 3, pp. 559-82.

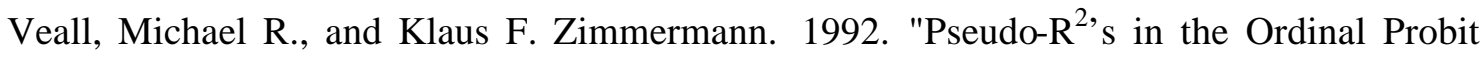
Model." Journal of Mathematical Sociology, Vol. 16, pp. 332-42.

Wagner, Gert G., Richard V. Burkhauser, and Friederike Behringer. 1993. "The English Language Public Use File of the German Socio-Economic Panel." Journal of Human Resources, Vol. 28, No. 2, pp. 429-33.

Weinkopf, Claudia. 2002. „"Es geht auch anders"- Reguläre Beschäftigung durch Dienstleistungspools." In C. Gather, B. Geissler, and M. S. Rerrich, eds., Die Normalisierung der Hausarbeit im informellen Sektor. Münster: Verlag Westfälisches Dampfboot, pp. 15466.

Wolff, Edward N. 1985. "The Disappearance of Domestic Servants and the Underground Economy," In Wolfram Gaertner and Alois Wenig, The Economics of the Shadow Economy. Springer, pp. 316-29.

WSI Tarifarchiv. 2002. "Tätigkeiten mit niedriger tariflicher Grundvergütung," Düsseldorf: Hans Böckler Stiftung. 


\section{IZA Discussion Papers}

\begin{tabular}{|c|c|c|c|c|}
\hline No. & Author(s) & Title & Area & Date \\
\hline 943 & $\begin{array}{l}\text { J. T. Addison } \\
\text { P. Teixeira }\end{array}$ & $\begin{array}{l}\text { What Have We Learned About the Employment } \\
\text { Effects of Severance Pay? Further Iterations of } \\
\text { Lazear et al. }\end{array}$ & 3 & $11 / 03$ \\
\hline 944 & $\begin{array}{l}\text { H. Görg } \\
\text { D. Greenaway }\end{array}$ & $\begin{array}{l}\text { Much Ado About Nothing? Do Domestic Firms } \\
\text { Really Benefit from Foreign Direct Investment? }\end{array}$ & 2 & $11 / 03$ \\
\hline 945 & $\begin{array}{l}\text { R. Schöb } \\
\text { D. E. Wildasin }\end{array}$ & $\begin{array}{l}\text { Economic Integration and Labor Market } \\
\text { Institutions: Worker Mobility, Earnings Risk, and } \\
\text { Contract Structure }\end{array}$ & 2 & $12 / 03$ \\
\hline 946 & M. Leonardi & $\begin{array}{l}\text { Earnings Instability of Job Stayers and Job } \\
\text { Changers }\end{array}$ & 1 & $12 / 03$ \\
\hline 947 & U. Sunde & $\begin{array}{l}\text { Potential, Prizes and Performance: Testing } \\
\text { Tournament Theory with Professional Tennis } \\
\text { Data }\end{array}$ & 7 & $12 / 03$ \\
\hline 948 & $\begin{array}{l}\text { A. Kugler } \\
\text { G. Pica }\end{array}$ & $\begin{array}{l}\text { Effects of Employment Protection and Product } \\
\text { Market Regulations on the Italian Labor Market }\end{array}$ & 6 & $12 / 03$ \\
\hline 949 & C. J. Flinn & $\begin{array}{l}\text { Minimum Wage Effects on Labor Market } \\
\text { Outcomes under Search with Bargaining }\end{array}$ & 6 & $12 / 03$ \\
\hline 950 & $\begin{array}{l}\text { P. Garibaldi } \\
\text { E. Wasmer }\end{array}$ & $\begin{array}{l}\text { Equilibrium Employment in a Model of Imperfect } \\
\text { Labor Markets }\end{array}$ & 1 & $12 / 03$ \\
\hline 951 & $\begin{array}{l}\text { P. Garibaldi } \\
\text { E. Wasmer }\end{array}$ & $\begin{array}{l}\text { Raising Female Employment: Reflexions and } \\
\text { Policy Tools }\end{array}$ & 5 & $12 / 03$ \\
\hline 952 & $\begin{array}{l}\text { O. Raaum } \\
\text { K. G. Salvanes } \\
\text { E. Ø. Sørensen }\end{array}$ & The Neighbourhood Is Not What It Used to Be & 3 & $12 / 03$ \\
\hline 953 & $\begin{array}{l}\text { O. Raaum } \\
\text { K. G. Salvanes } \\
\text { E. Ø. Sørensen }\end{array}$ & $\begin{array}{l}\text { The Impact of a Primary School Reform on } \\
\text { Educational Stratification: A Norwegian Study of } \\
\text { Neighbour and School Mate Correlations }\end{array}$ & 5 & $12 / 03$ \\
\hline 954 & $\begin{array}{l}\text { P. Portugal } \\
\text { J. T. Addison }\end{array}$ & Six Ways to Leave Unemployment & 6 & $12 / 03$ \\
\hline 955 & V. Grossmann & $\begin{array}{l}\text { Risky Human Capital Investment, Income } \\
\text { Distribution, and Macroeconomic Dynamics }\end{array}$ & 5 & $12 / 03$ \\
\hline 956 & $\begin{array}{l}\text { M. Fertig } \\
\text { C. M. Schmidt }\end{array}$ & $\begin{array}{l}\text { Gerontocracy in Motion? European Cross- } \\
\text { Country Evidence on the Labor Market } \\
\text { Consequences of Population Ageing }\end{array}$ & 5 & $12 / 03$ \\
\hline 957 & $\begin{array}{l}\text { M. Ebell } \\
\text { C. Haefke }\end{array}$ & $\begin{array}{l}\text { Product Market Deregulation and Labor Market } \\
\text { Outcomes }\end{array}$ & 6 & $12 / 03$ \\
\hline 958 & $\begin{array}{l}\text { T. Brück } \\
\text { J. P. Haisken-DeNew } \\
\text { K. F. Zimmermann }\end{array}$ & $\begin{array}{l}\text { Creating Low Skilled Jobs by Subsidizing } \\
\text { Market-Contracted Household Work }\end{array}$ & 5 & $12 / 03$ \\
\hline
\end{tabular}

An updated list of IZA Discussion Papers is available on the center's homepage www.iza.org. 